\title{
THE IMPACT OF THE D727E POLYMORPHISM HAS NO SIGNIFICANT ROLE IN MULTI NODULAR GOITER
}

\author{
Tug $\mathrm{E}^{1}$, , Sengül N², Aydin $\mathrm{H}^{3}$, Yilmaz EE ${ }^{2}$
}

*Corresponding Author: Esra Tug, M.D., Ph.D., Gazi University, Faculty of Medicine, Department of Medical Genetics, 06500 Ankara, Turkey; Tel.: +90-312-202-69-44; Fax: +90-312-202-46-35; E-mail: esratug@hotmail.com

\begin{abstract}
Interactions between individual genetic and environ-mental factors determine the onset of the multi nodular goiter (MNG). The thyroid-stimulating hormone receptor (TSHR) gene is a convincing candidate gene in the pathogenesis of certain thyroid diseases including MNG. We investigated the codon 727 polymorphism (p.Asp727Glu, p.D727E) of the human TSHR gene using the polymerase chain reaction-restriction fragment length polymorphim (PCR-RFLP) methods in 31 Turkish patients with MNG and in 30 control subjects, aiming to evaluate the relationship between this polymorphism and MNG. After genomic DNA isolation, PCR amplification was performed using a pair of primers in exon 10 of the TSHR gene that contains the p.D727E polymorphism and digested by theNlaIII (Hin 1II) restriction enzyme. We found the $\mathrm{CC}$ and $\mathrm{CG}$ genotype incidence for the patient group to be 0.71 and 0.29 , respectively, and for the control group to be 0.8 and 0.2 , respectively. No statistically significant difference was found between the genotype and allele distribution of both groups ( $p=0.417$ and $p=0.449$, respectively). However, the polymorphism is significantly correlated with the low serum level of the TSH $(p=0.047)$. These results suggest that the p.D727E polymorphism of the TSHR gene
\end{abstract}

${ }^{1}$ Gazi University, Faculty of Medicine, Department of Medical Genetics, Ankara, Turkey

2 Abant Izzet Baysal University, Faculty of Medicine, Department of Surgery, Bolu, Turkey

${ }^{3}$ Istanbul University, Cerrahpasa Medical Faculty, Department of Medical Genetics, Istanbul, Turkey may not contribute to the pathogenesis of nontoxic MNG diseases.

Keywords: Multi nodular goiter (MNG); Codon 727 polymorphism; p.D727E; Thyroid-stimulating hormone receptor (TSHR) gene

\section{INTRODUCTION}

Goiter is the volumetric enlargement of the thyroid gland [1]. Benign nodular goiter is a heterogenous thyroid disorder. It can be divided into solitary nodular and multi nodular thyroid disease. Multi nodular goiter (MNG) constitutes a mixed group of nodular entities. Structural and functional heterogeneity is the most characteristic feature of MNG [2,3]. The term toxic MNG comprises a spectrum of clinical entities, ranging from a single hyper functioning nodule within an enlarged thyroid gland that also contains non functioning nodules, to multiple hyper functioning areas scattered throughout the gland $[4,5]$. The thyroid-stimulating hormone (TSH, thyrotropin) controls thyroid function and growth. Its receptor (TSHR) activates the $\alpha$ subunit of the stimulatory $\mathrm{G}$ protein $(\mathrm{Gs} \alpha)$, leading to adenylate cyclase (AC) activation and cyclic AMP (cAMP) production [6,7]. The TSHR gene, located on chromosome 14q31, has been cloned and sequenced [8]. Polymorphisms have been detected in TSHR exon $10[9,10]$. The diallelic polymorphism in which a cytosine/ guanine base transition occurs at nucleotide position 2281 within codon 727 (c.2281 C>G), results in the substitution of glutamic acid for aspartic acid (p.Asp727Glu; p.D727E) in the intracellular portion of the receptor, has been associated with toxic or non toxic MNG, the expression of the p.D727E 
variant in eukaryotic cells resulting in an exaggerated cAMP response to thyrotropin stimulation. After TSH stimulation of the polymorphic variant according to the wild type TSHR gene increased cAMP accumulation. Thus, p.D727E could induce growth and function of thyrocytes [1]. We have investigated the frequency of this p.D727E polymorphism in Turkish patients with MNG and in control subjects, aiming to evaluate the relationship between this polymorphism and MNG.

\section{MATERIALS AND METHODS}

We studied 31 consecutive Turkish patients with MNG who underwent total thyroidectomy at the Department of General Surgery, Abant Izzet Baysal Medical School, Bolu, Turkey. The Abant Izzet Baysal University Ethics Committee had approved the study (\#2009/100-78) and written informed consent was obtained from all subjects after full description of the objectives and procedures of the study.

Every patient underwent radioimmunology analysis of serum TSH, free thyroxine (FT4), free triiodothyronine (FT3) and thyroid autoantibodies (TPOAb, TGAb) before surgery and medical therapy for hyperthyroidy. According to the results of thyroid function tests, thyroid ultrasonography and a thyroid technetium $99 \mathrm{~m}(99 \mathrm{mTc})$ scintigraphy, the patients were divided into toxic (subclinical hyperthyroidism and hypertyroidism) MNG, and non toxic MNG. None of the patients had mental illnesses, systemic diseases (neurological or other endocrine), acute or chronic inflammatory or autoimmune diseases. Seventy-five percent of the patients have a positive family history of MNG.

Thirty healthy subjects attending the outpatient laboratory of the hospital with no history or evidence of MNG and no first-degree relatives with hyperthy- roidism were recruited as control group. The patients and controls were unrelated Turkish subjects residing in the Bolu region, in northwest Turkey. The demographic characteristics and laboratory criterion of the patients and controls are shown in Table 1.

Venous blood $(3 \mathrm{~mL})$ was collected from subjects into EDTA-coated tubes, and genomic DNA was extracted using the QIAamp DNA Blood Mini Kit (Qiagen, Hilden, Germany). A pair of primers was designed to flank the region in exon 10 of the TSHR gene that contains the p.D727E polymorphism (rs1991517), as previously described [11]. To amplify the 196 bp DNA product containing the polymorphic site, primers 5'-CTC AGC AAG TTT GGC ATC TG-3" (forward) and 5'-CTT CTG AGA TTT GGC CTT GC-3' (reverse) were used [http://innere. uniklinikum-leipzig.de/tsh/frame.html].

Polymerase chain reaction (PCR) was used to amplify genomic DNA in a $25 \mu \mathrm{L}$ reaction volume containing 2.5 $\mu \mathrm{L}$ genomic DNA (20-50 ng), $1.5 \mu \mathrm{L}$ $\mathrm{MgCl}_{2}(25 \mathrm{mM}), 1 \mu \mathrm{L} \mathrm{dNTP}(2.5 \mathrm{mM}) 1 \mu \mathrm{L}$ forward $\operatorname{primer}(20 \mathrm{ng} / \mu \mathrm{L})$ and $1 \mu \mathrm{L}$ reverse primer $(20 \mathrm{ng} / \mu \mathrm{L})$ and $0.1 \mu \mathrm{L}$ Taq DNA Polymerase $(5 \mathrm{U} / \mu \mathrm{L})$ (Vivantis Technologies, Selangor Malaysia), in the PCR buffer provided by the manufacturer $(10 \mathrm{mmol} / \mathrm{L}$ Tris- $\mathrm{HCl}$, $\mathrm{pH} 8.0$, and $100 \mathrm{mmol} / \mathrm{L} \mathrm{KCl}$ ). The PCR involved an initial denaturation at $95^{\circ} \mathrm{C}$ for $3 \mathrm{~min}$., followed by 35 cycles of denaturation at $95^{\circ} \mathrm{C}$ for 30 seconds, annealing at $56^{\circ} \mathrm{C}$ for 30 seconds, and extension at $72^{\circ} \mathrm{C}$ for 30 seconds, with a final extension at $72^{\circ} \mathrm{C}$ for $4 \mathrm{~min}$., using a thermocycler (Takara, Shiga, Japan). The PCR amplification product was $196 \mathrm{bp}$ long. To detect the $\mathrm{C}>\mathrm{G}$ substitution, we used the NlaIII (Hin 1II) (Fermentas, Vilnius, Lithuania) restriction enzyme. The G allele fragments were 129 and $67 \mathrm{bp}$ long, while those for the $\mathrm{C}$ allele were 108, 67 and 21 bp long (Figure 1).

Table 1. The demographic characteristics of the patients and controls.

\begin{tabular}{|c|c|c|c|}
\hline & Patients & Controls & $p$ Value \\
\hline Age (years) & $53.03 \pm 11.22(36-77)$ & $61.76 \pm 6.80(50-77)$ & 0.001 \\
\hline Gender: males/ females & $8 / 23$ & $3 / 27$ & 0.111 \\
\hline FT4 (ng/ dL) & $1.41 \pm 0.51(0.95-3.19)$ & $1.18 \pm 0.15(0.91-1.49)$ & 0.059 \\
\hline FT3 (pg/ dL) & $3.48 \pm 1.54(1.47-8.31)$ & $2.86 \pm 0.34(2.39-3.63)$ & 0.206 \\
\hline TSH (mIU/ L) & $0.51 \pm 0.68(0.00-2.10)$ & $1.56 \pm 1.32(0.17-6.10)$ & 0.003 \\
\hline $\begin{array}{c}\text { Family history of goiter: } \\
\text { - positive }\end{array}$ & $20(65.0 \%)$ & & 0.000 \\
\hline
\end{tabular}

FT4: free thyroxine; FT3: free triiodothyronine; THS: thyroid-stimulating hormone (thyrotropin). 


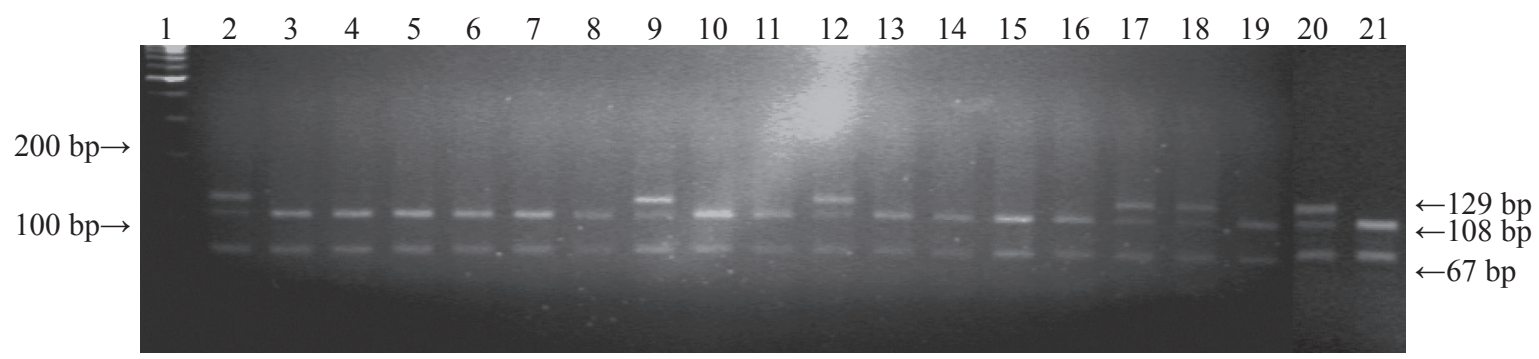

Figure 1. The PCR-based restriction analysis of the p.D727E polymorphisms of the TSHR gene shown on $2 \%$ agarose electrophoresis. The NlaIII (Hin 1II) restriction enzyme cuts in the CATG/G region. In the presence of 129 and $67 \mathrm{bp}$, the fragments were shown to be GG (polymorphic homozygote) genotype; in the presence of 108, 67 and $21 \mathrm{bp}$, the fragments were shown to be be CC (wild type) genotype; in the presence of 129, 108, 67 and $21 \mathrm{bp}$, the fragments were shown to be CG (polymorphic heterozygote) genotype. Lane 1 was loaded with appropriate molecular markers; lanes 2, 9, 12, 17, 18, 20 are heterozygous $\mathrm{CG}$ subjects; lanes 3, 4, 5, 6, 7, 8, 10, 11, 13, 14, 15, 16, 19, 21 are homozygous CC subjects. A 21 bp fragment was not seen in either CC or CG genotypes.

Statistical analysis was done by using SPSS software package. Mann-Whitney U tests and Chi-square tests were used whenever appropriate and a $p$ value of $<0.05$ was considered significant.

\section{RESULTS}

Clinical evaluation of the patients is shown in Table 2. Table 3 shows the distribution of the codon 727 genotypes of the TSHR gene (CG heterozygous; $\mathrm{CC}$ wild type) in patients and controls. In addition, the $\mathrm{C}$ and $\mathrm{G}$ allele frequencies of patient and control groups are given in Table 3 .

Table 2. The clinical evaluation of the patients.

\begin{tabular}{|c|c|}
\hline Parameters & Patients (\%) \\
\hline Thyroid disorder: & \\
- toxic MNG & $48.39(n=15)$ \\
- non toxic MNG & $51.61(n=16)$ \\
\hline Thyroid function: & \\
- hyperthyroid & $51.61(n=16)$ \\
- subclinical hyperthyroid & $22.58(n=7)$ \\
- euthyroid & $25.81(n=8)$ \\
\hline
\end{tabular}

MNG: multi nodular goiter.
We did not find a homozygous G allele (GG genotype) in our groups. There was no statistically significant difference between the genotype and allele distribution of the two groups ( $p=0.417$ and $p=$ 0.449 , respectively). Moreover, there was no significant difference in family history between the groups with respect to alleles $(p=0.959)$. However, the subtypes of toxic thyroid disease (toxic and subclinical $\mathrm{MNG}$ ) were not related to significant differences in polymorphism frequencies compared with the non toxic MNG and control group, while the p.D727E polymorphism is significantly correlated with the low serum level of TSH $(p=0.047)$.

\section{DISCUSSION}

We screened the p.D727E polymorphism of the TSHR gene, a predisposition factor causing MNG. The statistical analysis of our data did not show a direct relationship between the p.D727E polymorphism and non toxic MNG in our groups. Clearly, the presence of the p.D727E polymorphism in the TSHR gene is not sufficient for the development of nodular goiter, because, according to our results, ap-

Table 3. The distribution of the p.D727E genotypes and allelic frequencies of the TSHR gene in patients and controls.

\begin{tabular}{|c|c|c|c|c|c|}
\hline & \multicolumn{3}{|c|}{ NlaIII Genotype } & \multicolumn{2}{c|}{ Allele Frequency } \\
\hline & $\mathrm{C} / \mathrm{C}$ & $\mathrm{G} / \mathrm{G}$ & $\mathrm{C} / \mathrm{G}$ & $\mathrm{C}$ & $\mathrm{G}$ \\
\hline Patients $(n=31)$ & $70.97 \%(n=22)$ & $-(n=0)$ & $29.03 \%(n=9)$ & $53(85.48 \%)$ & $9(14.52 \%)$ \\
\hline Controls $(n=30)$ & $80.00 \%(n=24)$ & $-(n=0)$ & $20.00 \%(n=6)$ & $54(90.00 \%)$ & $6(10.00 \%)$ \\
\hline
\end{tabular}

$\mathrm{CC}$ : wild type genotype; GG: homozygous genotype; CG: heterozygous genotype. 
proximately $20.0 \%$ of normal individuals possess this polymorphism. In addition, despite a small number of patients, there was no correlation between the polymorphism and toxic MNG, however, frequency of polymorphism is associated with low TSH level.

Gabriel et al. [1] indicated that a p.D727E polymorphism of the human TSHR gene was significantly associated with toxic MNG. They argued that altered intracellular signaling of the variant receptor after stimulation by TSH might participate in the pathogenesis of toxic MNG. However, Gabriel et al. [1] reported that the presence of the heterozygous state for the p.D727E polymorphism of the TSHR gene was not solely responsible for the development of the disease, and that this variant existed in approximately $10.0 \%$ of normal individuals. This rate was higher than that in our control group. Also, Gozu et al. [12] reported similar geographic differences in the prevalence of the TSHR polymorphisms.

Thyrotropin receptor polymorphisms and thyroid hyper functioning after the first identification is still an unresolved question. Muhlberg et al. [13] studied the frequency of the polymorphism p.D727E in a large group of patients with non autoimmune hyper functioning thyroid disorders in a European Caucasian population. They demonstrate that there is no association with the gene polymorphism with toxic goiter. However, the presence of the TSHR polymorphism may predispose to hyper functioning, but in abnormal growth and nodular goiter pathogenesis, other genetic or environmental factors may be effective. However, in cases of less functional impairment, a contribution of variants of this gene in the etiology of non toxic goiter is possible.

In conclusion, taking into consideration the fact that the p.D727E TSHR variant is frequently detected in the general population, it would seem that it represents a simple polymorphism and probably is not involved in the development of thyroid diseases. However, positive family history of MNG in $65.0 \%$ of our patients suggests that there may be another related gene or genes responsible for the development of MNG in our population. This is the first study of the p.D727E polymorphism in Turkish patients with MNG. According to our data, the p.D727E variant is frequently detected in the general population; it would seem that it represents a plain polymorphism and is probably not involved in the development of structural thyroid disease. Further studies are nec- essary to examine factors that orchestrate thyroid nodular transformations, and which genetic traits are associated with this process.

\section{REFERENCES}

1 Gabriel EM, Bergert ER, Grant CS, Van Heerden JA, Thompson GB, Morris JC. Germline polymorphism of codon 727 of human thyroid-stimulating hormone receptor is associated with toxic multinodular goiter. J Clin Endocrinol Metab. 1999; 84(9): 3328-3335.

2. Derwahl M, Studer H. Nodular goiter and goiter nodules: where iodine deficiency falls short of explaining the facts. Exp Clin Endocrinol Diabetes. 2001; 109(5): 250-260.

3. Paschke R. Molecular pathogenesis of nodular goiter. Langenbecks Arch Surg. 2011; 396(8): 1127-1136.

4. Hay ID, Morris JC. Toxic adenoma and toxic multinodular goiter. In: Braverman LE, Utiger RD, Eds. Werner and Ingbar's the Thyroid. Philadelphia: Lippincott-Raven. 1996:566-572.

5. Hamburger JI. The autonomously functioning thyroid nodule: Goetsch's disease. Endocr Rev. 1987; 8(4): 439-450.

6. Tonacchera M, Pinchera A. Thyrotropin receptor polymorphisms and thyroid diseases. J Clin Endocrinol Metab. 2000; 85(8): 2637-2639.

7. Hansen PS, van der Deure WM, Peeters RP, Iachine I, Fenger M, Sørensen TI, Kyvik KO, Visser TJ, Hegedüs L. The impact of a TSH receptor gene polymorphism on thyroid-related phenotypes in a healthy Danish twin population. Clin Endocrinol. 2007; 66(6): 827-832.

8. Rousseau-Merck MF, Misrahi M, Loosfelt $\mathrm{H}$, Atger M, Milgrom E, Berger R. Assignment of the human thyroid stimulating hormone receptor (TSHR) gene to chromosome 14q31. Genomics. 1990; 8(2): 233-236.

9. Akamizu T. Antithyrotropin receptor antibody: an update. Thyroid. 2001; 11(12): 1123-1134.

10. Sykiotis GP, Neumann S, Georgopoulos NA, Sgourou A, Papachatzopoulou A, Markou KB, Kyriazopoulou V, Paschke R, Vagenakis AG, Papavassiliou AG. Functional significance of the thyrotropin receptor germline polymorphism 
D727E. Biochem Biophys Res Commun. 2003; 301(4): 1051-1056.

11. Musa M, Harun F, Mat Junit S. Molecular analysis of the thyroid stimulating hormone receptor gene in unrelated patients with congenital hypothyroidism. Asia Pac J Mol Biol Biotechnol. 2008; 16(3): 65-69.

12. Gozu H, Avsar M, Bircan R, Claus M, Sahin S, Sezgin O, Deyneli O, Paschke R, Cirakoglu B, Akalin S. Two novel mutations in the sixth transmembrane segment of the thyrotropin receptor gene causing hyperfunctioning thyroid nodules. Thyroid. 2005; 15(4): 389-397.

13. Muhlberg T, Herrmann K, Joba W, Kirchberger M, Heberling HJ, Heufelder AE. Lack of association of nonautoimmune hyperfunctioning thyroid disorders and a germ line polymorphism of codon 727 of the human thyrotropin receptor in a European Caucasian population. J Clin Endocrinol Metab. 2000; 85(8): 2640-2643. 